Thorax (1972), 27, 583.

\title{
Mitral valve replacement with stored inverted pulmonary homograft valve ${ }^{1}$
}

\author{
JANE SOMERVILLE ${ }^{2}$, DONALD ROSS, and J. KEITH ROSS \\ National Heart Hospital, London W.1
}

The fate is described of 11 patients who had a stored pulmonary valve homograft mounted on a frame or in a Dacron jacket used for mitral valve replacement. Mitral regurgitation due to holes in the attenuated cusps occurred in nine by one year, requiring re-operation or causing death. Only one patient remains well with moderate mitral regurgitation after two years.

Since January 1967,118 patients have had mitral valve replacement with a preserved cadaver semilunar homograft valve mounted in a jacket or frame (Murray, Roschlau, and Lougheed, 1956 ; Heimbecker et al., 1962). In all except 11 patients the aortic valve was used.

However, in the 11 patients in whom an inverted pulmonary valve was used (Lower, Stofer, and Shumway, 1961) the clinical course has been different. The purpose of this report is to draw attention to the problems and discourage the use of this form of mitral valve replacement.

\section{MATERIAL}

Between September 1968 and April 1969, 11 patients aged 24 to 66 years had mitral valve replacement with an inverted stored pulmonary valve homograft. The valves in five were sterilized by gamma-irradiation and in five by ethylene oxide. These valves were flash frozen and stored at $-79^{\circ} \mathrm{C}$. There is no record of the method of preparation in one.

In five patients the valve was mounted on a Dacron or Teflon covered strut of polypropylene (one RossKay, one lonescu, one Cutter) and in six it was wrapped in a Dacron or Teflon jacket (Yacoub and Kittle, 1969).

All patients had severe and disabling symptoms at the time of operation and had had full medical treatment for a minimum of six months. Six had chronic congestive failure and three had had previous valve surgery. Five patients had homograft replacement of another valve at the same operation, and one 61-yearold had replacement of the ascending aorta for a dissecting aneurysm. There were no operative deaths. Clinical follow-up included regular documentation of the symptoms, physical signs, electrocardiogram, and chest radiograph. Recatheterization was undertaken on five after symptomatic deterioration. The gross appearance of the pulmonary valve was noted at death or re-operation, but histology was not available.

\section{RESULTS}

The follow-up of patients with a pulmonary valve in the mitral position varied from two weeks to

1Supported by a grant from the British Heart Foundation

2Requests for reprints to: Jane Somerville, Institute of Cardiology, 35 Wimpole Street, London W1 M8EX two and a half years and the clinical findings are shown in the Table. Some of these patients lived for a longer period after replacement of the pulmonary homograft by a Starr or fascia lata valve. Six patients required re-operation for mitral regurgitation two weeks to 15 months after the initial replacement, and one of these died. In the patient operated on at two weeks, the graft had become detached from its jacket and folded inwards, causing mitral obstruction as well as regurgitation.

Of the remaining five patients, three died from heart failure three months, 14 months, and 15 months after operation, one is in severe heart failure 22 months later and has had re-operation, and the other (R.D.), who has signs of mitral regurgitation, is ambulant with a limited effort tolerance two and a half years after operation. Clean holes in the thin central part of one or more cusps were found in seven patients, and in four, two cusps were attenuated and thinned. In one (C.M.) the strut split, and in another (J.K.) a cusp had split away from the jacket and there was a separate hole in an attenuated cusp; in another (A.R.) there was central regurgitation but no holes. The valve was well incorporated but there was an exposed area of Dacron covered with platelet thrombus which might have been the source of embolism.

One patient had been unconscious from the time of operation with a tetraplegia; the mitral valve at three months had a hole in one thinned cusp 
T A B L E

SUMMARY OF CLINICAL DATA, FATE, AND MACROSCOPICAL PATHOLOGY: 11 PATIENTS WITH INVERTED PULMONARY HOMOGRAFT REPLACEMENT OF THE MITRAL VALVE

\begin{tabular}{|c|c|c|c|c|c|c|c|c|c|c|c|c|c|}
\hline \multirow{2}{*}{ Case } & \multirow{2}{*}{$\begin{array}{l}\text { Age } \\
(y r)\end{array}$} & \multirow{2}{*}{ Disease } & \multirow{2}{*}{ Op. Date } & \multirow{2}{*}{ Sterilize } & \multirow{2}{*}{$\begin{array}{l}\text { J } \\
\text { or } \\
\text { F }\end{array}$} & \multirow{2}{*}{$\begin{array}{c}\text { Other } \\
\text { Procedure }\end{array}$} & \multirow{2}{*}{ Ant. } & \multicolumn{6}{|c|}{ After Operation } \\
\hline & & & & & & & & $\begin{array}{l}\text { Pan } \\
\text { SM }\end{array}$ & LHF & $\begin{array}{l}\text { Re-op. } \\
\text { Date }\end{array}$ & $\begin{array}{c}\text { Pathology } \\
\text { Mitral }\end{array}$ & Complication & $\begin{array}{c}\text { State } \\
\text { Aug. 1971 }\end{array}$ \\
\hline J.K. & 43 & $\begin{array}{l}\text { Calcific } \\
\text { MS }\end{array}$ & Sept. 1968 & $\gamma$ Eth. $\mathbf{O}$ & $\mathbf{J}$ & - & $1 / 12$ & $2 / 12$ & $9 / 12$ & $\begin{array}{l}\text { Sept. } 1969 \\
\text { St. }\end{array}$ & $\begin{array}{l}\text { Holes }+ \\
\text { split from }\end{array}$ & $\begin{array}{l}\text { Pulm. cerebral } \\
\text { embolus }\end{array}$ & $\begin{array}{l}\text { Dec. } 1969 \\
\text { Died }\end{array}$ \\
\hline P.K. & 46 & $\begin{array}{l}\text { Calcific } \\
\text { MS }\end{array}$ & Oct. 1968 & $\gamma$ Fr. & $\mathbf{J}$ & 一 & + & $1 / 52$ & $6 / 12$ & Oct. 1970 & $\begin{array}{l}\text { Jacket } \\
\text { Holes } 2 \\
\text { thin cusps }\end{array}$ & 一 & $\begin{array}{l}\text { AR mild } \\
\text { Well }\end{array}$ \\
\hline C.W. & 45 & $\begin{array}{l}\text { TR,MR } \\
\text { AR }\end{array}$ & Nov. 1968 & $\gamma$ & $\mathbf{J}$ & Ao.Ho. & + & $\begin{array}{l}1 / 12 \\
\text { TR }\end{array}$ & $15 / 12$ & $\begin{array}{c}\text { June } 1971 \\
3 \text { St. }\end{array}$ & $\begin{array}{l}\text { Holes } 2 \\
\text { thin cusps }\end{array}$ & $\begin{array}{l}\text { Ascites } \\
\text { oedema }\end{array}$ & $\begin{array}{l}\text { Well } \\
\text { Haemo- }\end{array}$ \\
\hline A.R. & 54 & MR, MS & Dec. 1968 & Fr. & $\mathbf{J}$ & - & + & $\begin{array}{l}9 / 12 \\
\text { TR }\end{array}$ & $22 / 12$ & Oct. 1971 & $\begin{array}{l}\text { Central } \\
\text { leak. No }\end{array}$ & $\begin{array}{l}\text { RHF } \\
\text { Cerebral }\end{array}$ & $\begin{array}{l}\text { III } \\
\text { R + LHF }\end{array}$ \\
\hline C.H. & 43 & $\begin{array}{l}\text { Calcific } \\
\text { MS, AR }\end{array}$ & Dec. 1968 & Eth. $\mathrm{O}$ & $\mathbf{J}$ & $\begin{array}{l}\text { Ao.Ho. } \\
1966\end{array}$ & + & $2 / 52$ & $2 / 52$ & Feb. 1969 & $\begin{array}{l}\text { Graft } \\
\text { split }\end{array}$ & $\begin{array}{l}\text { emoolus } \\
\text { Ao.Ho. } \\
\text { Re-op. }\end{array}$ & Well \\
\hline R.D. & 61 & $\begin{array}{l}\text { MR, } \\
\text { aneurysm }\end{array}$ & Feb. 1969 & Eth. $\mathrm{O}$ & $\mathbf{J}$ & $\begin{array}{l}\text { Repl. } \\
\text { ascending } \\
\text { aorta }\end{array}$ & - & $4 / 12$ & - & - & Irom ring & $\begin{array}{l}\text { Aug. } 1969 \\
\text { Syst. cerebral } \\
\text { embolus }\end{array}$ & $\begin{array}{l}\text { Ambulant } \\
\text { psychosis }\end{array}$ \\
\hline J.E. & 47 & MR, TR & Feb. 1919 & $?$ & $\mathbf{F}$ & $\begin{array}{l}\text { Ao.Ho. } \\
\text { Tr. }\end{array}$ & - & $4 / 12$ & $14 / 12$ & - & $\begin{array}{l}\text { No } \\
\text { necropsy }\end{array}$ & $\begin{array}{l}\text { Pneumonia } \\
\text { Pulm. } \\
\text { embolus TR }\end{array}$ & $\begin{array}{l}\text { Died } \\
\text { April } 1970\end{array}$ \\
\hline I.R. & 24 & & Mar. 1969 & $\begin{array}{l}\text { Eth. O } \\
\text { Fr. }\end{array}$ & $\mathbf{F}$ & & $1 / 12$ & & & $\begin{array}{l}\text { July } 1969 \\
\text { FL }\end{array}$ & $\begin{array}{l}\text { Holes } 2 \\
\text { thin cusps }\end{array}$ & $\begin{array}{l}\text { Pulm. } \\
\text { embolus }\end{array}$ & Well \\
\hline A.M. & 40 & $\begin{array}{l}\text { MR, MS, } \\
\text { TR, TS }\end{array}$ & Mar. 1969 & $\gamma$ Eth. $O$ & $\mathbf{F}$ & $\begin{array}{l}\text { Pulm. Ho. } \\
\text { Tr. }\end{array}$ & + & $?$ & $?$ & & $\begin{array}{l}\text { Holes } 1 \\
\text { avulsion }\end{array}$ & & $\begin{array}{l}\text { Died } \\
\text { May } 1970\end{array}$ \\
\hline M.T. & 66 & $\begin{array}{l}\text { Calcific } \\
\text { MS }\end{array}$ & April 1969 & Eth. $\mathrm{O}$ & $\mathbf{F}$ & - & + & $1 / 12$ & $?$ & - & $\begin{array}{l}\text { Hole } 1 \\
\text { cusp }\end{array}$ & Unconscious & $\begin{array}{l}\text { Died } \\
\text { July } 1969\end{array}$ \\
\hline C.M. & 36 & MR, MS & Sept. 1969 & $\gamma$ Fr. & $F$ & 一 & + & $4 / 12$ & $5 / 12$ & $\begin{array}{l}\text { Sept. } 1970 \\
\text { St. }\end{array}$ & $\begin{array}{l}\text { Hole } 1 \\
\text { cusp } \\
\text { strut split }\end{array}$ & TR & Well \\
\hline
\end{tabular}

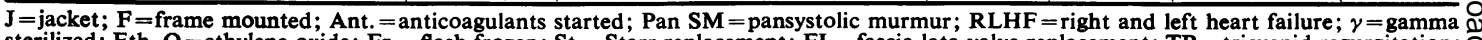
sterilized; Eth. $\mathbf{O}=$ ethylene oxide; Fr. = flash frozen; St. =Starr replacement $; \mathbf{F L}=$ fascia lata valve replacement; TR $=$ tricuspid regurgitation; $\mathrm{O}$ Tr. = tricuspid valve; $M S=$ mitral stenosis; $M R=$ mitral regurgitation; $A R=$ aortic regurgitation; Ao.Ho. $=$ aortic homograft; $T S=$ tricupid $\mathbb{D}$ stenosis.

and a regurgitant murmur had appeared at one month. The pathology of the valve was not known in two patients as no necropsy was done in one and the other (R.D.) has not had re-operation.

A clear pansystolic murmur was documented two weeks to four months after operation in nine patients, and in six, reliable auscultators had not noted evidence of mitral regurgitation in the early postoperative weeks. Severe left heart failure usually occurred one to 12 months later, although in two, pulmonary oedema occurred quickly after the appearance of the murmur.

Systemic emboli occurred in three patients one month, 18 months, and 22 months after operation and none was on anticoagulants at the time of embolism, although in one (A.R.) with the late embolus, anticoagulants had been given for the first postoperative month. The other eight patients had anticoagulants for a minimum of two months with no embolic problems.

\section{DISCUSSION}

The use of the pulmonary valve in the mitral position was tried because of its larger size in comparison with the aortic valve and also because of shortage of cadaver homografts. As can be seen from this experience, the results have been unsatisfactory; there was deterioration in six patients before six months had elapsed and a? further three were in left heart failure by one year. $\vec{F}$ Two patients remain well after 18 months and only one after two years. The gross pathology of $\stackrel{0}{x}$ the valve was similar in all patients with attenua- $\frac{0}{3}$ tion of cusps and holes or splitting away from the ring. It is possible that the method of steriliza- $\delta$ tion or storage may have weakened the valves as $₹$ this group includes the early gamma-irradiated $\frac{\text { 임 }}{3}$ valves. However, of the 23 inverted aortic valves $D$ in the mitral position either jacketed or framemounted and sterilized in the same way, there N have been four with mitral regurgitation needing re-operation or causing death. The usual cause was 0 tearing of the valve away from the frame with $\mathbb{N}^{\circ}$ attenuation of the cusps and holes in the thinned areas in only one.

It thus appears that the pulmonary homograft $\frac{}{\infty}$ valve may not be adequate, as suggested by Angell, $\stackrel{?}{+}$ Wuerflein, and Shumway (1967), for use in the mitral position, although a small experience using ${ }_{\overparen{P}}$

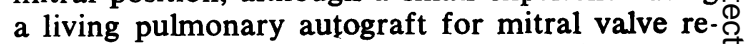
placement (Ross, 1967) has been promising over $\stackrel{\mathbb{Q}}{\Omega}$ a two- to three-year period in three patients. 0 Attenuation with holes has been seen in one 
patient with a frame-mounted pulmonary autograft after three months. Experience with the living pulmonary autograft is too small to know whether its fate will be the same as that of the pulmonary homograft. Rigid frame-mounted valves in the mitral position impose unusual stresses, and if the valve is weakened by sterilization or in basic design, failure may often occur quickly. It is likely to be a combination of factors which causes the failure of the pulmonary homograft.

From the above experience it is suggested that the stored pulmonary homograft valve mounted or jacketed is not suitable for mitral valve replacement.

We are grateful to Dr. R. Emanuel, Dr. G. Hayward, and Dr. A. Leatham, whose patients were included in this series; also to Miss Tina Jesson for technical assistance, and to Miss Sheila Gardener, the radiographer.

\section{REFERENCES}

Angell, W. W., Wuerflein, R. D., and Shumway, N. E. (1967). Mitral valve replacement with the fresh aortic valve homograft: Experimental results and clinical application. Surgery, 62, 807.

Heimbecker, R. O., Baird, R. J., Lajos, T. Z., Varga, A. T., and Greenwood, W. F. (1962). Homograft replacement of the human mitral valve. A preliminary report. Canad. med. Ass. J., 86, 805.

Lower, R. R., Stofer, R. C., and Shumway, N. E. (1961). Total excision of the mitral valve and replacement with the autologous pulmonic valve. J. thorac. cardiovasc. Surg., 42, 696.

Murray, G., Roschlau, W., and Lougheed, W. (1956). Homologous aortic-valve-segment transplants as surgical treatment for aortic and mitral insufficiency. Angiology, 7, 466.

Ross, D. N. (1967). Replacement of aortic and mitral valves with a pulmonary autograft. Lancet, $2,956$.

Yacoub, M. H., and Kittle, C. F. (1969). A new technique for replacement of the mitral valve by a semilunar valve homograft. J. thorac. cardiovasc. Surg., 58, 859. 